\title{
SELF-REGULATED LEARNING STRATEGIES AS PREDICTORS OF SENIOR SECONDARY SCHOOL STUDENTS' CHEMISTRY ACHIEVEMENT IN ONDO STATE, NIGERIA
}

TELLA, A. PhD

Dept. of Science, Mathematics and Technology Education, University of Ibadan, Nigeria

\begin{abstract}
The study investigated on self- regulated learning strategies as predictors of Chemistry students' attitude to Chemistry in senior secondary schools in Ondo State. The research adopted survey research design. 400 students were used for the research work which was drawn randomly using simple random sampling technique. The research instruments for the study were SRLS questionnaire containing 10 items on each of the component and students' attitude to Chemistry (SATC) questionnaire with 25 items. The validity of the instruments was assessed and found to be adequate by the experts. Cronbach alpha was used to determine the reliability of SRLS with a coefficient of 0.86, 0.89, 0.85 and 0.96 and 0.78 for (SATC) at 0.05 level of significance. The data collected was analysed using descriptive and inferential statistics such as: mean standard deviation, Pearson Product Moment Correlation and Analysis of Variance. The study revealed that there was significant relationship between goal setting ( $r$ $=0.063 ; P>0.05)$ and students' achievement in Chemistry. Self- monitoring $(r=0.025 ; P<0.05)$, selfevaluation $(r=0.012 ; P<0.05)$ and self-efficacy $(r=0.064 ; P<0.05)$ had significant relationship with students' achievement in Chemistry. The result also revealed that there was no composite contribution of SRLS on students' achievement in Chemistry $\left(F_{(4,395)}=0.673 ; P>0.05\right)$. None of the independent variables predicts students' achievement in Chemistry. Based on the findings it was recommended that students should be encouraged to develop enough self-regulated learning strategies that will facilitates their learning while Government should supply new materials like Chemistry textbooks so that students would be exposed to more facts about Chemistry and teachers on their part should improve themselves academically whenever such opportunity are available so that they can get better.
\end{abstract}

Keywords: Self- Regulated Learning Strategies, and Achievement

\section{Introduction}

Science (derived from the Latin word scientia which means "knowledge") is a systematic enterprise that builds and organizes knowledge in the form of testable explanations and predictions about the universe. Science also refers to a body of knowledge that can be rationally explained and reliably applied. Science has been viewed as an instrument that aids development in many countries. It plays important and dominant roles in spear heading technological advancement, promoting national wealth, improving health and accelerating industrialization (Validya, 2003 as cited in Adebayo 2013). The importance of science cannot be over emphasized, as it can be felt in medicine, communication, transportation, security, and agriculture (Sreed Haran, 2011; Borlaug, 2000; Melchtry 2013). During the twentieth century, science through agriculture research ensured food security through the green, white and yellow revolutions aided by genetic engineering, use of artificial fertilizers and carefully executed irrigation systems, and many developing countries benefited (HOHC Gimenez, 2008).

In Nigerian, basic science is compulsory for the first nine years of a child spends in school, the next three years before university studies provides options in chemistry, physics and biology for students interested in pursuing a science based course at higher level (Federal Ministry of Education, 2007). Chemistry is one of the science subjects upon which technological breakthrough is built and is the pivot on which the 

Achievement in Ondo State, Nigeria

wheel of science rotates. Chemistry has been defined by Redmond (2008) as a science that deals with the fundamental constituents of the universe, the forces they exert on one another and the results produced by these forces. Chemistry is essentially a practical oriented subject which demands proper exhibition of good study behavior for effective interpretation of existing phenomena (Njelita, 2008). Raymond Change (1998) described chemistry as the study of matter and the change it undergoes. Life is made more meaningful with chemical productions such as drugs, cosmetics, paints, soaps, fertilizer.

Chemistry as a science subject in school is different from other non-science subject in the school curriculum in the sense that its lessons take place in laboratories where both students and teachers carry out experiments and practical demonstration (Abimbola and Ado, 2007). Chemistry teaching can only be result-oriented when students are willing and the teachers are favorably disposed using the appropriate methods and resources in teaching the students. Senior secondary school chemistry curriculum in Nigeria is a multi-agency approach to curriculum development (Adesoji and Olatunbosun 2008). It was jointly developed by the Federal Ministry of Education (formerly known as Comparative Education Study and Adaptation Center CESAC), National Education Research Council (NERC), West African Examination Council (WAEC) and Science Teacher Association of Nigeria (STAN). The objectives developed for the chemistry curriculum with the desire to cater for contemporary needs of the nation as a country aspiring to be among the first twenty (20) economics in the world by the year 2020, are outlined as follows:

I. Develop interest in the subject of chemistry.

II. Acquire basic theoretical and practical knowledge and skills.

III. Acquire and develop reasonable level of competence in ICT, applications that will engender entrepreneurship skills.

IV. Develop and acquire interest in science, technology and mathematics

V. Apply skills to meet societal needs of creating employment and wealth.

VI. Positioned to take advantage of the numerous career opportunities offered by Chemistry.

VII. Adequately prepared for further studies in chemistry.

The re-viewed curriculum shows Chemistry and its inter-relationship with other subjects and its links with industry and everyday life activities and hazards. These objectives appear to be in line with the national policy on science education and it seeks to achieve what the national goals were aimed at, but well outlined and unambiguous objectives, does not mean these objectives are entirely relevant to the child and society, neither does it guarantees its achievability. Abuseyi (2007) observed that in spite of the various innovations introduced into science teaching generally and Chemistry in particular, the performance of students still remains poor. This is buttressed by the poor performance of student in Chemistry in the West African Senior Certificate Examinations (WASCE) (Adajumobi \& Ivowi 1992; Adeyegbe 1992; Ezeudu 1995). Senior Secondary School Certificate examination results in Chemistry released by WAEC have revealed the poor achievement of secondary School candidates in May/June Senior Secondary School Certificate Examination, in Chemistry between (2000-2016) in Nigeria. 
Commenting on poor students' achievement in chemistry, scholars like Akpan (2004), Ezeliora (2004), Nweze (2004), Ngozi and Ndokwu 92007), Ogwa (2008) and Udo and Udofia (2014) remarked that instructional strategies such as lecture method adopted by the teacher during instructional delivery and student factors constitute major factors of students' failure in chemistry examinations. Also as observed by Njoku (2007), poor achievement in chemistry can be attributed to lack of appropriate formal reasoning ability and acquisition of science process skills. There seems to be a general consensus among science educators concerning the critical role played by the instructional strategy adopted by the teacher as one of the factors affecting students' achievement and science process skills development in chemistry. Emphasising the importance of appropriate teaching strategy in the development of science process skills required for science content knowledge acquisition.

A learning strategy is defined as a "'conscious "plan that integrates a set of specific behaviors in order to accomplish a recurring task successfully (Bail 2004). According to literature, using learning strategies is a significant way that student learn how to regulate their academic behaviors (Weinslein and Mayer, 1986). The term "Selfregulated" can be used to describe learning that is guided by metacognition which simply means thinking about one's thinking. Zimmerman (2000); Winnie and Perry (2006) in their study opined that students who are self- regulated learners are cognizant of their academic strength and weaknesses and have a repertoire of strategies they apply to tackle day to day challenges of their academic task. This selfregulated learner belief that opportunities exist to take challenging task, practice their learning to develop a deep understanding of the subject and exert effort that will give rise to academic success. Many researchers agreed that self-regulated learning is a multi-dimensional process in which there is a set of four recurring phases, in a general ordered sequence that materializes the attainment of self-regulated skills. The phases are: forethought, control, self- monitoring and self-reflection. Self-regulated learning(SRL) is a learning that is guided by metacognition (thinking about one's thinking), strategic action, planning, monitoring and evaluating personal progress against a standard and motivation to learn.

Self-regulating students use leaning strategies as the tools to make changes anywhere along this triadic feedback loop in order to accomplish an academic task. This strategy may include setting clear and realistic goals, monitoring and evaluating progress and managing resources such as time, environment and effort. Choosing the best strategy is a continuous and interactive process between the students' behavioural outcomes, personal efforts and environment (Zimmerman, 1989) Thus, identifying students' learning strategies becomes very important in dictating how educators can help student score higher on pen- and- paper test/chemistry tests and examinations. Zimmerman and Martinez (1986) isolated the effective self-regulated learning strategies which are: Self -evaluation, organizing and transforming, goal setting and planning, seeking information, keeping records and monitoring, environmental structuring, self-consequences, rehearing and memorizing, seeking social assistance, reviewing records and others. This study therefore intends to investigate four selfregulated strategies: goal setting, self- monitoring, self-evaluation and self-efficacy out of many isolated strategies of Zimmerman and Martinez (1986) considering Nigeria classroom situations. 
Goal setting involves establishing specific measurable, achievable, realistic and timetargeted (SMART). Self-regulated students during the process of preparing for an examination by setting either goals or the outcome they expect to receive for efforts such as praise from one's parents, getting good grades for college, or experiencing internal satisfaction when students receive an A grade on an examination is major motivating factors that determines whether students will attempt to learn. Setting goals relates to academic achievement because goals provide specific performance standards by which students can gauge their progress. Research shows that the type of goals students set are related to academic achievement. Students who set mastery goals are more likely to perform better than students who set only performance goals (Kitsantas, 2002). Self-monitoring is defined as deliberately paying attention to an aspect of one's behaviour (Brenan \& Schloemer, 2003). It is also defined as a personality trait that refers to an ability to regulate behaviour to accommodate social situation.

Self-monitoring helps students focus their attention on and discriminate between effective and ineffective performance and reveals inadequate strategies. Research has shown that students who monitor their progress towards their goals, especially mastery goals, display higher skill acquisition (Schunk \& Ertiner, 2000; Jeffrey, 2005). Self-evaluation is the process by which the self-concept is socially negotiated and modified. It occurs when individuals respond to their efforts and modify their learning strategies by comparing outcomes of performance with a standard goal (Shunk and Etiner, 2000). Students who are self- regulated often evaluate their performance. During self-evaluation, replacement of strategies with more effective ones is done; students seek assistance from other students and restructures learning environment so that it is conducive for learning, as a result, students who have poor grades performs better. During self-evaluation rising of metacognitive awareness is also compulsory (Chen, 2002).

Self-efficacy is the extent or strength of one's belief in one's own ability to complete tasks and reach goals. Self -efficacy is also called perceived ability. Psychologist like Albert Bandura has defined self-efficacy as one's belief in one's ability to succeed in specific situations. Self-efficacy is a person's judgment about being able to perform a particular activity. Effective self-regulation depends on feeling self-efficacious for using skills to achieve mastery (Bandura, 1986; Bouffard-Bouchard, 1991; Zimmerman, 1994). Positive self -evaluations of progress indicates to student that their learning strategies are working, which increases their self- efficacy. Self-efficacy has its root in the social cognitive theory formulated by Bandura (1986). Self-efficacy influences goal setting, achievement of efforts towards goal and persistent in the face of difficulty.

\section{Statement of the Problem}

The fact that student's performance is poor in Chemistry at the senior secondary school level is no longer news. Records have shown that senior secondary school chemistry students have the problem of underachievement in public examinations. Several factors have been identified to be responsible for this poor students' achievement and prominent among them as revealed in literature are instructional strategy used in teaching chemistry such as the use of lecture method, poor 
demonstration of science process skills, abstract nature of chemistry, students' personality, variables like gender stereotype, attitude, interest, self-concepts, unqualified teachers, lack of instructional materials among others. Previous studies concentrated on the development of various teaching instructional strategies at the neglect of examining the influence of self-regulated learning strategies. This study, therefore, investigated on the influence of the self-regulated learning strategies as it affects student's Chemistry achievement in Chemistry.

\section{Purpose of the Study}

This study used self-regulated learning strategies to analyse students' performance at the various aspects of senior secondary school Chemistry. This study identified how students have been performing in Chemistry with the use of self- regulated learning strategies.

\section{Research Questions}

1. What is the relationship between independent variables on students' achievement in Chemistry?

2. What is the composite contributions of independent variables students' achievement in Chemistry?

3. What is the relative contributions of independent variables on students' achievement in Chemistry?

4. To what extent will each of the independent variables predict students' achievement in Chemistry?

\section{Methodology}

The research design for this study is survey research design. Ten randomly selected senior secondary schools in Ondo West Local Government Area were used for this study. Ten senior secondary schools were randomly selected in Ondo Town, the schools were co-educational secondary schools, SSS II students in the school were used because they have been exposed to some topics in Chemistry for three terms and the schools have at least two graduate Chemistry teachers. In each of the ten selected schools forty students were used from SSS II and in all a total of four hundred (400) students participated in the study. The researcher used two sets of instruments for this study and these are self-regulated learning strategies questionnaire (SRLS) and Chemistry students achievement test (CSAT).

\section{Results}

The data were presented and analysed as follows:

Research Question 1: What is the relationship between independent variables (Goal Setting Self-monitoring, Self-evaluation and Self-efficacy) on students' achievement in Chemistry? 
Self-Regulated Learning Strategies as Predictors of Senior Secondary School Students' Chemistry Achievement in Ondo State, Nigeria

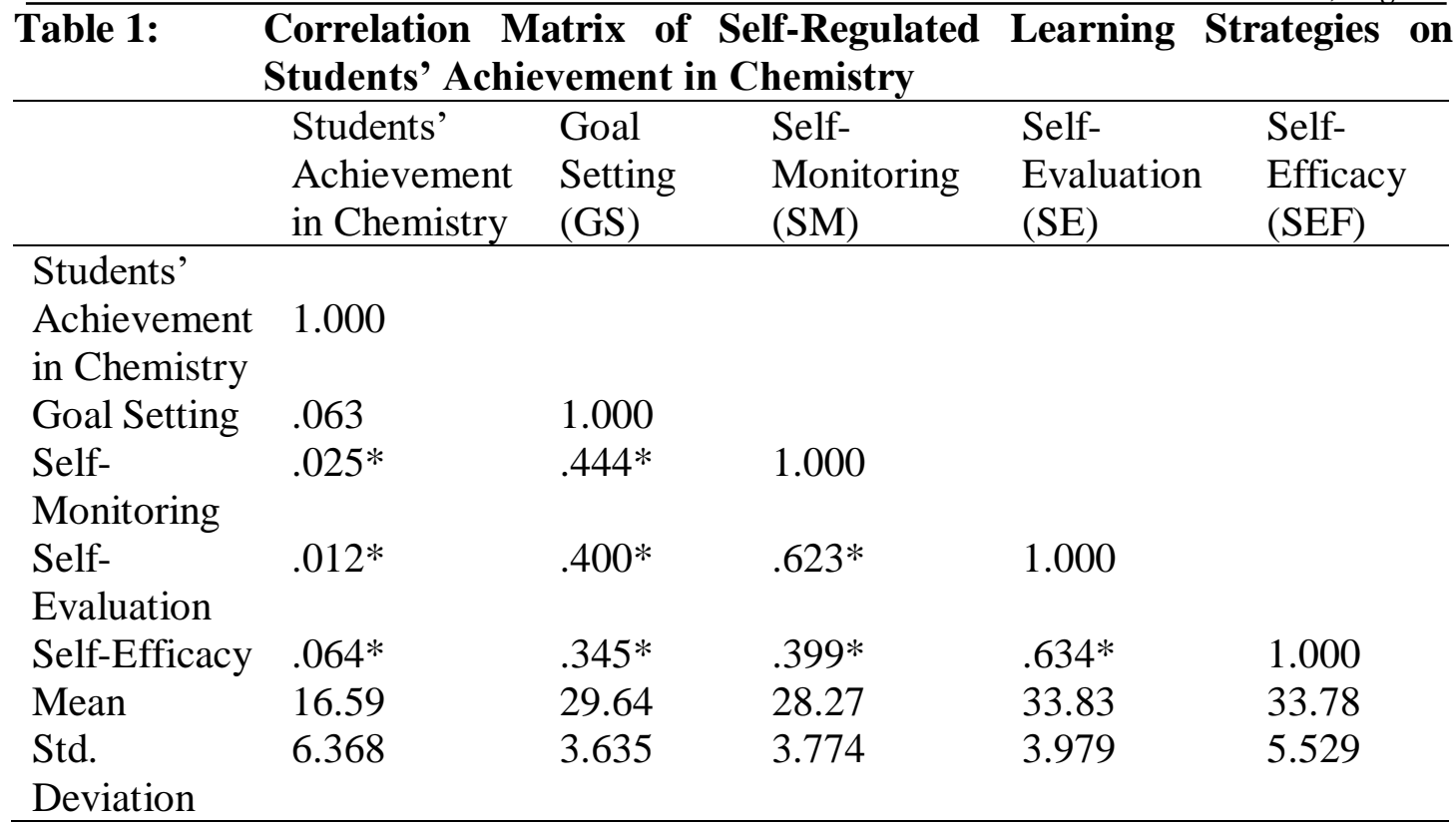

*Denotes correlation at 0.05 level of significant.

Table 1 shows that there is significant correlation between students achievement in Chemistry and self-monitoring $(\mathrm{r}=0.025 ; \mathrm{P}<0.05)$. It implies that, self-monitoring is related to students' achievement in Chemistry. Also self-evaluation correlates significantly with students' achievement in Chemistry $(\mathrm{r}=0.012 ; \mathrm{P}<0.05)$. This means that self-evaluation is also related to students' achievement in Chemistry. Also selfefficacy also has a positive significant correlation with students' achievement in Chemistry $(\mathrm{r}=0.064 ; \mathrm{P}<0.05)$. This shows that self-efficacy correlates significantly with students' achievement in Chemistry. However, there is no correlation between students' achievement in Chemistry and goal setting ( $\mathrm{r}=0.063 ; \mathrm{P}>0.05)$. This means that goal setting is not positively correlated to students' achievement in Chemistry.

Research Question 2: What is the composite contribution of independent variables (goal setting, self-monitoring, self-evaluation and self-efficacy) on students' achievement in Chemistry?

Table 2: Summary of Multiple Regression Analysis on Composite Contributions of Self-Regulated Learning Strategies on Students' Achievement in Chemistry.

\begin{tabular}{|c|c|c|c|c|c|}
\hline Model & $\begin{array}{l}\text { Sum } \\
\text { squares }\end{array}$ & $\mathrm{Df}$ & $\begin{array}{l}\text { Means } \\
\text { Square }\end{array}$ & $F$ & Sig \\
\hline Regression & 109.536 & 4 & 27.384 & .673 & .64 \\
\hline Residual & 16069.574 & 395 & 40.682 & & \\
\hline Total & 16179.110 & 399 & & & \\
\hline $\begin{array}{ll}\mathrm{R} & = \\
\mathrm{R}^{2} & =\end{array}$ & $\begin{array}{r}.082 \\
007\end{array}$ & & & & \\
\hline
\end{tabular}

Adjusted $\mathrm{R}^{2}=.003$

Std. Error of the Estimate $=.003$ 
Table 2 shows that the composite contribution of independent variables of goal setting, self-monitoring, self-evaluation and self-efficacy was not significant. The $\mathrm{F}$ value ratio of the result $(\mathrm{F}(4,395)=0.673 ; \mathrm{P}>0.05)$ shows that there is no composite contribution. Table4.3 (a) also reveals a multiple regression adjusted $\left(\mathrm{R}^{2}\right)$ of 0.003 . This implies that $0.3 \%$ of the total variation in the achievement of students in Chemistry is not attributable to the composite contributions of independent variables of goal setting, self-monitoring, self-evaluation and self-efficacy.

Research Question3: What is the relative contribution of independent variables (goal setting, self-monitoring, self-evaluation and self-efficacy on students' achievement in Chemistry?

Table 3: $\quad$ Summary of Multiple Regression Showing Relative Contribution of Independent variables on Students' Achievement in Chemistry.

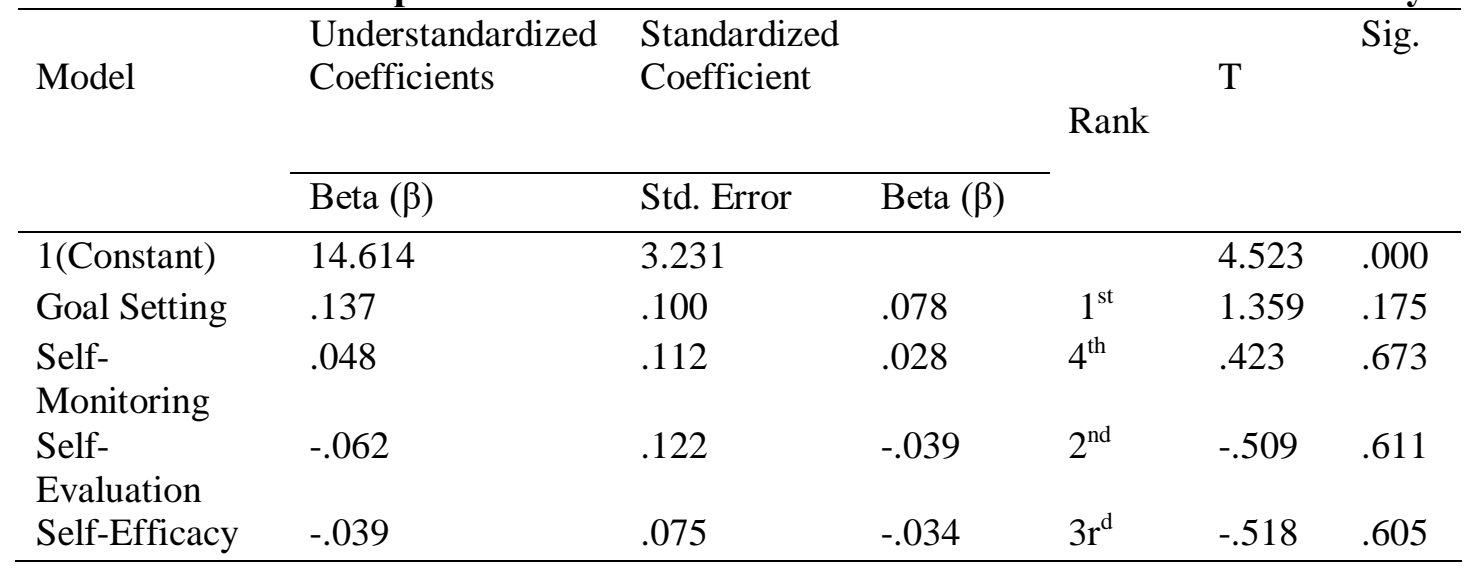

Table 3 reveals that the relative contributions of each of the independent variables on students' achievement in Chemistry. The relative contributions of goal setting on students' achievement in Chemistry was not significant $(\beta=.078 ; \mathrm{t}=1.359, \mathrm{P}>0.05)$. Self-monitoring on students' achievement in Chemistry was not significant also $(\beta=.028 ; \mathrm{t}=.0423 ; \mathrm{P}>0.05)$. Also, the relative contribution of self-evaluation on students' achievement in Chemistry was not significant $(\beta=-.039, \mathrm{t}=-.059, \mathrm{P}>0.05)$, while that of self-efficacy on students' achievement was not also significant $(\beta=-.034$; $\mathrm{t}=-.518 ; \mathrm{P}>0.05)$. Thus, all the independent variables were not significant on the achievement of students in Chemistry. The relative contributions of each of the independent variables at different levels and ranks is shown as: GS $(\beta=.078 ; \mathrm{t}=1.259$; $\mathrm{P}>0.05)>$; $\mathrm{SE}(\beta=-.039 ; \mathrm{t}=-.509 \mathrm{P}>0.05)>$; $\mathrm{SEF} \quad(\beta=-.034 ; \mathrm{t}=-.518 ; \mathrm{P}>0.05) \quad>$; $\operatorname{SM}(\beta=.028 ; \mathrm{t}=.423 ; \mathrm{P}>0.05)$. Therefore, there is no relative contribution of independent variables to students' achievement in Chemistry.

Research Question 4: To what extent will each of the independent variables (goal setting, self-monitoring, self-evaluation and self-efficacy) predict students' achievement in Chemistry?

Table 3revealed that goal setting $(\beta=0.078 ; \mathrm{t}=1.359 ; \mathrm{P}>0.05)$, self-monitoring $(\beta=0.028 ; \mathrm{t}=0.423 ; \mathrm{P}>0.05)$, self-evaluation $(\beta=-0.039, \mathrm{t}=-0.509 ; \mathrm{P}>0.05)$ and selfefficacy $(\beta=-0.034 ; \mathrm{t}=-0.518 ; \mathrm{P}>0.05)$ had no significant relative contribution on students' academic achievement in Chemistry. Therefore, none of the independent variables predicts achievement in Chemistry. The prediction equation is given by 
$\mathrm{Y}=14.614$

Where $\mathrm{Y}=$ achievement score in Chemistry

\section{Discussion on findings}

The findings of this study showed a negative relationship between goal setting and achievement in Chemistry. The findings that revealed that there is no significant relationship between goal setting and students' achievement negates the findings of Kitsantas (2002) who reported that goal setting relates to academic achievement because they provide specific performance standards by which students can gauge their progress. The result of this study is at variance with the work carried out by (Boekarts, 2002; Edwins; 1995; Giraffee and Templi, 1997; Schunk, 2003), that goal setting affects performance and enhances achievement. The findings of this study also revealed a positive significant relationship between self-monitoring and achievement in chemistry. The result that showed a positive significant relationship between selfmonitoring and achievement in Chemistry is in accordance with the research work conducted by Jeffrey (2005) on the relationship between self-monitoring and achievement of high school Chemistry which involved sixty-one college high school male students who found that self-monitoring affects test performance. Selfevaluation has positive significant relationship with students' achievement in Chemistry. Positive significant on students' achievement in Chemistry may be due to the fact that the students evaluate themselves very well on Chemistry than other subjects. Ingakall and Insa (2011) reported a positive result on the research work titled effects of self-evaluation on students' achievement in Chemistry education; they found that students of the self-evaluation grouped achieved higher learning outcomes than students of the control group. Their research work also revealed that there seems to be more positive feelings towards the learning unit when students work with the self-evaluation sheet. Self-efficacy has positive significant relationship with students' achievement in Chemistry. Positive significant on students' achievement in Chemistry may be due to the fact that students have ability to handle and solve some problems in Chemistry. Mohammed et al (2011) reported a positive result on a research work titled relationship between self-efficacy and academic achievement in high school students, in the study 250 students in the academic year 2010/2011 were selected by means of multistage cluster sampling and complicated self-efficacy scale grade point average in classes was used to measure the achievement score. In their findings, they concluded that self-efficacy influences the academic achievement of the high school students. The findings of this study on composite contributions of the four independent variables revealed that there is no significant contribution of the independent variables on achievement. The lack of significance contributions of the four independent variables on achievement may be due to the fact that the students find it difficult to work on these variables or make use of these variables on Chemistry as a subject. The findings of this study on relative contributions of the four independent variables revealed that there is no significant relative contribution of the independent variables on students' achievement in Chemistry. The findings of the result on relative contributions of the independent variables which have no effect on students' achievement in Chemistry can be attached to low sensitization of students on the importance of goal setting, self-monitoring, self-evaluation and self-efficacy. 
Table 3: revealed that goal setting $(\beta=0.078 ; \mathrm{t}=1.359 ; \mathrm{P}>0.05)$, self-monitoring $(\beta=0.028 ; \mathrm{t}=0.423 ; \mathrm{P}>0.05)$, self-evaluation $(\beta=-0.039, \mathrm{t}=-0.509 ; \mathrm{P}>0.05)$ and selfefficacy $(\beta=-0.034 ; \mathrm{t}=-0.518 ; \mathrm{P}>0.05)$ had no significant relative contribution on students' academic achievement in Chemistry.

\section{Conclusion}

The focus of the study has examined the extent to which self-regulated learning strategies (Goal setting, self-monitoring, self-evaluation and self-efficacy) would predict students' achievement in Chemistry in senior secondary schools. Findings from this study have established that the approach to teaching of Chemistry through the independent variables is effective at improving students' level in Chemistry. Three out of the four independent variables in the study have significant relationship to students' achievement in Chemistry while goal-setting is not significant on students' achievements. In order to increase students' Chemistry achievement in secondary schools, teacher should conduct effective Chemistry teaching activities and provide instruction on self-regulated learning strategies. Chemistry teachers should instruct their student's in such a way as to enable them to monitor, control and evaluate their own learning.

\section{Recommendations}

Based on the findings of the study, it is recommended that:

1. Students should be encouraged to develop enough self-regulated learning strategies that will change their performance in Chemistry.

2. Students should be encouraged to be active participants of their own learning by having their learning controlled.

3. Teachers should on their part should go for in-service training and endeavour to further their education when such opportunities avail itself, as science has been defined as a body of knowledge that is dynamic.

4. Teacher training programmes should include self-regulated learning strategies to enable teachers to encourage the students to develop it and for the teachers to teach effectively in the classroom. Chemistry teachers should be adequately trained on the use of these strategies.

5. The government at both Federal and State level should endeavour to provide textbooks to the public schools for the students to make use of in order to increase their intellectual horizon and give adequate financial allocation to schools in other to reduce the trend of failures in chemistry, especially in a developing Nation like Nigeria where exposition of students to science cannot be over emphasized. 


\section{References}

Abimbola, I. O. (1998). An assessment of the provision of science infrastructural facilities in the secondary schools of Kwara state. Unilorin pedagogue, 5: 515.

Abuseyi, F. A. (2007). Student and teacher related variables as determinants of secondary school students' academic achievement in chemistry.

Adeleye, R. A. (2012). Analysis of students' performance on the different aspects of senior secondary school chemistry practical in Oyo state. M. Ed. Dissertation Faculty of Education, University of Ibadan.

Adesoji, F. A. (2002).Rethinking the science curriculum. In J. A. Ajala (Ed.).Designing content of the curriculum: Guide to practice Ibadan. My best publications.

Adesoji, F. A. and Olatunbosun, S. M. (2008). Student, teacher and school environment factors as determinants of achievement in senior secondary school chemistry in Oyo State Nigeria. The journal of international social research, 1 (2): 13-34

Agusiobo, (1998).Relationship between Learning Resources and Student's Academic Achievement in Science Subjects in Taraba State Senior Secondary Schools. Academic Journal, 20 (1).

Akpan, E. U. U. (2004). Lofty career prospects as the unknown obstacles in the students' poor achievement in chemistry. The Journal of Education, 7 (1): 1 11 .

Bandura, A. (1986). Social foundations of thought and action: A social cognitive theory. Englewood cliffs NJ: Prentice hall. Educational Journal, 3.

Chen, C. S. (2002). Self-regulated learning strategies and achievement. Man introduction to information systems courses. Information technology, learning and performance journal, 20 (1): 11-15.

Ezeliora, B. 2004. Motivating secondary school science teachers to face the challenges of third millennium. Journal of the Science Teachers Association of Nigeria, 39(1): $82-88$.

Federal Government of Nigeria 2004. National policy on Education (Revised). Abuja, Nigerian Educational Research and Development Council (NERDC)

Jeffrey, S. (2005). The relationship between self-regulatory learning strategies and the academic achievement of high school chemistry students. Thesis University of Hawait. 
Kitsantas, A. (2002). Test preparation and performance. A self-regulatory analysis. The Journal of Experimental Educational, 70 (1): 101-113

Mohammad, S. E.; Motlageh, Kourosh, A. and Hosseinsouri, (2011). The relationship between self efficacy and academic achievement in high school.

Ngozi, D. and Ndokwo, K. J. (2007). Issues in human resources development for science technology and mathematics education in Nigeria. Proceedings of the $50^{\text {th }}$ International Conference of Science Teachers Association of Nigeria. Ibadan, 19-22.

Ngozi, Z. C. (2007). Comparison of students' achievement in the three categories of questions in SSCE practical chemistry examination. Journal of Science Teachers Association of Nigeria, 42 (1 and 2): 67 - 72.

Nweze, T. (2004). Developing instructional and social capital through appropriate teaching strategies. A case study for annual and perennial course review. Ebonyi State Journal of Education, 2 (1): 77 - 85.

Ogunleye, B. O. and Babajide, V. F. T. (2011a). Generative instructional strategy enhances senior secondary school students' achievement in Physics. European Journal of Educational Studies, 3(3): 453 - 463.

Ogwa, C. E. (2008). Identification of important teaching skills necessary for the successful teaching of introducing technology at junior secondary schools. Ebonyi State Journal of Education, 3 (1): 77 - 85.

Udo, M. E. and Udofia, T. M. (2014). Effect of mastery learning strategy on students' achievement in symbols, formulae and equations in chemistry. Journal of Educational Research and Review, 2(3): 28 - 35.

Weinstein and Mayer (1986.Instruction of Learning Strategies: Effects on Conceptual Learning and Learning Satisfactions. International Article, 12(1).

Winnie, A. and Perry, L. (2006). Constructing scientific knowledge in the classroom. Educational research, 23(7): 5-12.

Zimmerman, B. J. (1986). A social cognitive view of self-regulated academic learning Journal of educational psychology, 181 (3): 329-339.

Zimmerman, B. J. (2000). Theories of self regulated learning and academic achievement. An overview and analysis in R.J Zimmerman \& D. H. Schunk (Ed). Self-regulated learning and academic achievement: Theoretical perspectives. Mabroah, NJ: Lawrence Erlbam. 